\title{
Robert Blatchford's The Sorcery Shop: Another Socialist Utopia
}

The Sorcery Shop de Robert Blatchford : une autre utopie socialiste

\section{Martine Faraut}

\section{(2) OpenEdition \\ 12 Journals}

\section{Electronic version}

URL: http://journals.openedition.org/rfcb/3293

DOI: $10.4000 /$ rfcb.3293

ISSN: 2429-4373

\section{Publisher}

CRECIB - Centre de recherche et d'études en civilisation britannique

\section{Printed version}

Date of publication: 1 September 2004

ISBN: 2-911580-19-2

ISSN: 0248-9015

\section{Electronic reference}

Martine Faraut, «Robert Blatchford's The Sorcery Shop: Another Socialist Utopia », Revue Française de Civilisation Britannique [Online], XIII-1 | 2004, Online since 01 September 2004, connection on 07 October 2019. URL : http://journals.openedition.org/rfcb/3293 ; DOI : 10.4000/rfcb.3293

This text was automatically generated on 7 October 2019.

\section{cc)}

Revue française de civilisation britannique est mis à disposition selon les termes de la licence Creative Commons Attribution - Pas d'Utilisation Commerciale - Pas de Modification 4.0 International. 


\title{
Robert Blatchford's The Sorcery Shop: Another Socialist Utopia
}

The Sorcery Shop de Robert Blatchford : une autre utopie socialiste

\author{
Martine Faraut
}

\section{Introduction}

1 When in 1890, a Manchester journalist, Robert Blatchford (1851-1943), who had witnessed at first hand the awful deprivations of working-class life in the slums, founded The Clarion, a weekly newspaper, in order to 'convert England to Socialism in seven years', four conflicting organisations were busy preaching the gospel of socialism in Britain: the (Marxist) Social Democratic Federation led by Henry Hyndman, whom he knew personally, the Fabian Society under the softer banner of the Webbs, the Socialist League formed by William Morris, whom Blatchford read and admired, ${ }^{1}$ and the Independent Labour Party (launched by Keir Hardie, a Lanarkshire miner) - which Blatchford had helped found and unsuccessfully tried to persuade Morris to chair. In spite of their separate affiliations and although there were some theoretical differences between William Morris and Robert Blatchford as to the means of achieving socialism, the two men agreed wholeheartedly on its general aims and shared the common dream of a better world based on communistic freedom, brotherhood and equality:

The purpose of the Socialist Movement is to arouse the people, to uplift the souls of the people, to destroy the evil theories of individualism and class pride, to reorganise society to establish collective ownership of the means of life, to abolish poverty and war, to convert the world to a new faith, to inspire it with a new hope, to weld the peoples into one human family. ${ }^{2}$

2 Morris and Blatchford, unlike many other socialist leaders, ${ }^{3}$ believed in particular that utopia was a useful weapon of propaganda on the workers and, in 1893, The Clarion began serialising Blatchford's utopian treatise, Merrie England, for which he is best remembered. Indeed in terms of influence the book compared well with Tom Paine's The Rights of Man as the paper achieved a circulation upwards of 30,000 and a readership 
of thousands more. ${ }^{4}$ When Morris died, Blatchford, who had worshipped him, felt deeply grieved. ${ }^{5}$ In the 1906 general election the Labour Party returned twenty-nine MPs to Westminster but its campaign had disappointed Blatchford who anticipated that their policy would never bring about the socialism he and Morris had been longing for. He began to distance himself from the party ${ }^{6}$ and published another utopia, The Sorcery Shop, in his paper, whose sales now reached 74,000, hoping to be 'the dying voice of William Morris in a world thrilling to the new voice of H. G. Wells'. ${ }^{7}$ In many respects, the novel is an offshoot of News From Nowhere. While revising some of the criticisms about Blatchford's second and rather neglected utopian novel, the purpose of this article is to bring out the similar roots of the socialist faith of the two men.

Let us first establish that, contrary to what is argued for instance by Chris Waters, ${ }^{8}$ both utopists were equally convinced of the feasibility of an egalitarian society. The Sorcery Shop was intended to persuade the readers of The Clarion of 'the possibility of organising and carrying on a prosperous and healthy commune without calling in any other mechanical aids than those of which we are already the masters. ${ }^{9}$ According to Waters, the subtitle of The Sorcery Shop - 'an impossible romance' - suggests a pessimism which Morris does not display in News from Nowhere, which significantly ends with the sentence: 'If others can see it as I have seen it, then it may be called a vision rather than a dream'. ${ }^{10}$ This criticism cannot stand as, for its most part, The Sorcery Shop consists of a debate between a wizard and two MPs, one Conservative and one Liberal, ${ }^{11}$ clearly destined, in Blatchford's own words, 'to indicate the possibilities of communal efforts, to show what might be done with England by a united and cultured English people and to meet the common arguments brought against socialism by the Storms and the Jorkles'. ${ }^{12}$ Waters's opinion that Blatchford was less sanguine than Morris about human nature remains equally questionable as our analysis of the novel will show.

\section{A socialist paradise}

Like London in News From Nowhere, Manchester in The Sorcery Shop is set in a socialist era which has rid the city of ugly industrial features. Indeed Manchester has become a garden-city of breathtaking beauty; it abounds in clean rivers, picturesque villages, well-kept roads, flowery meadows, blossoming woods and 'passionately' singing birds; ${ }^{13}$ it is surrounded by lush forests 'more luminous than gems. ${ }^{14}$ Chapter two or 'Paradise regained', describes an environment in which Nature looks its best but is to a large extent man-made, in spite of the title. The utopian world of The Sorcery Shop shares many of the features of News from Nowhere not only regarding the magnificence of nature but also of architecture,$^{15}$ and a number of themes such as the relationships between the sexes - 'all love here is free"16 - or the value of work. As Morris had voiced it in Commonweal: 'The leisure which Socialism above all things aims at obtaining for the worker is also the very thing that breeds desire... desire for beauty, for knowledge, for more abundant life. ${ }^{17}$ A theory which Blatchford readily subscribed to in The Sorcery Shop:

It is a mistake to suppose that a man of genius works for money. His incentive is not gain, it is genius. The reward of the giver is in the giving. The reward of the artist is his art ... [The genius] has joy in his work, in his gifts, in his power. Why should a man be paid by men because he has been more blessed by nature ${ }^{18}$

5 And of course, as it should be in a 'socialist commonwealth', ${ }^{19}$ strict economic equality reigns between workers - 'doctors and dockers are paid the same $e^{20}$ - and industrial 
masters are a thing of the past: 'these people are their own workmen. They do not work for your profit or for the profit of any one person. They work for the general good and for their own pleasure'. ${ }^{21}$ In The Sorcery Shop the land has become pro bono publico, ${ }^{22}$ customs have been substituted for government and laws. ${ }^{23}$ School education has been replaced by the random study of nature ${ }^{24}$ and the teachings of discerning mothers. ${ }^{25}$ As in News from Nowhere, the Utopians like gathering in communal halls. The Guest House of The Sorcery Shop rivals the splendour of that imagined by Morris. It 'looks like a crystal beehive' in the middle of a cherry orchard and right amongst a sea of tulips ${ }^{26}$ and boasts several wall frescoes. From the industrial times the society of The Sorcery Shop has retained nothing except the 'judicious' use of a selection of fine labour-saving machines, ${ }^{27}$ another significant borrowing from Morris's News From Nowhere. Blatchford's novel turns into paraphrase when the travellers first meet a dustman who looks like a gentleman ${ }^{28}$ and then Bernard the dunce who does not like work. ${ }^{29}$ In any case it testifies to the immense inspirational influence not only of Morris's utopia but also of Morris's ideas on him.

Once it has done with the pictorial description of the utopian country and a 'noble panorama' of rustic scenes, ${ }^{30}$ the novel engages interestingly in a political debate about the merits of socialism over capitalism destined to counterattack the (supposedly) 'natural' laws vindicated by the classical economists to justify laissez-faire. The novel contains the traditional indictment of the capitalist system, ${ }^{31}$ its false values of competition, productivity, profit, luxury and waste now replaced by 'the bodily essentials of life': 'Food, clothing, shelter and fuel without excess'. ${ }^{32}$ Contrary to the prevailing view that 'the average man is ambitious', Blatchford claims instead that 'the average man [is] not very good not very bad'33 and can be easily contented by 'health, respect, food, a home, a wife and children, congenial recreation and congenial work ${ }^{34}$ - provided he is given a different ideal and environment. The belief of the effect of the environment on man is indeed the hallmark of all socialists but it is Blatchford's faith in the innate goodness of human nature that again makes him akin to Morris.

\section{Blatchford's faith in the innate goodness of man}

7 The naivety of some of Blatchford's assertions as regards the workings of the human soul can be quite offputting at first. Whether the wizard refuses to believe that 'the lust for money is not the strongest passion of the human heart'35 or declares: 'Men will not die for money' or 'Men will do good for the sake of good but will not do evil except for gain... The love of good is a constant element in human nature and... avarice is only an accidental and disturbing element ${ }^{\prime}{ }^{36}$ one is tempted to interpret it as a fit of wishful thinking. Such a stance becomes more understandable if one, first of all, keeps in mind the strong feelings of comradeship that Blatchford undoubtedly experienced when militating in socialist circles. It is no surprise to read twice in the novel: 'What is possible to a small party of friends is possible to a large nation of friends' ${ }^{37}$ Although when looking at human history his angle was deliberately optimistic - 'Does not history prove that for the sake of love, for the sake of duty, for the sake of truth, for the sake of pity, for the sake of faith, men and women have chosen poverty, obloquy, torture and death?'38 - Blatchford was not blinkered and, like Morris, knew that it was not realistic to expect everybody to comply with society rules. As in News From Nowhere, the ultimate social regulator is therefore public opinion or peer pressure - what the wizard calls 'the love of approbation'. ${ }^{39}$ For instance, as the wizard explains to the travellers, a man who leaves his wife finds it difficult to get 
another one or 'a man who shirked his work would be regarded much as we regard a gentleman who cheats at cards'. ${ }^{40}$

Such a position assumes however that the majority of men are sensible and selfdisciplined, which leads us to examine what made Blatchford so sanguine. To posit that men are not actuated by greed, laziness and the pursuit of personal profit does not stem so much from ingenuousness as from a faith in man which his personal observations on human nature - never devoid of a certain amount of cynicism ${ }^{41}$ - did not manage to shake. Indeed Blatchford as a true lover of humanity was haunted by its misery which he found unacceptable. He neither despaired of improving human nature nor gave up his dream of 'building a heaven on earth' ${ }^{42}$ because he sincerely believed man to be good in essence. ${ }^{43}$ When Jorkle argues that socialism is impossible because 'you cannot alter human nature', the wizard replies: 'I do not propose to try. It is only necessary to make the best of human nature as it stands. And to do that it is only necessary to alter the conditions'. ${ }^{44}$ These tenets are at the root of his socialist faith. In The Sorcery Shop the travellers discover indeed that 'a complete change of circumstances' has taken place. ${ }^{45}$

\section{Pleasure and leisure}

Blatchford, like Morris, has reintroduced pleasure in the very heart of work itself with a view to encouraging men's natural and spontaneous desire for more. On that point Morris and Blatchford stand apart from mainstream socialists. As Blatchford explained: 'Speaking for myself I may say that I have little interest in the political side of Socialism'. ${ }^{46}$ His desire was not simply like most socialists to obtain a reduction of working hours in order to enjoy a vast amount of free time but to make work itself pleasurable.

Blatchford was in fact convinced that men's needs were very scarce and easily fulfilled: 'Did you not know that one of the great wants of people was the want of amusement and pleasure. Have I not told you a hundred times that the people want cheering more than they want improving? ${ }^{47}$ In his imaginary future society leisure consists of 'music, dance, art, literature and science, sports's8 and there are pleasures galore: 'A really healthy man can find amusement in felling trees or running in a paper chase or climbing rocks or throwing stones at a post', claims the wizard of The Sorcery Shop. ${ }^{49}$ As in News From Nowhere, work in The Sorcery Shop has been made enjoyable. Not only do people carry out the work of their choice but it has an artistic value and is performed as much as possible in the midst of nature. The place it occupies in the Utopians' life is therefore very evocative of News From Nowhere. All are engaged in the higher arts and crafts of which they are so 'enamoured that it is not easy to drive them away from it'. ${ }^{50}$ Unsurprisingly England has become 'a nation of craftsmen, and artists and musicians' Utopians' 'chief amusement', 52 people quarrel to get as much of it as they can! ${ }^{53}$ The undistinguishable character of work and leisure was never in Blatchford the sign of a carefree existence spent rambling, cycling and choral singing, but evidence that he subscribed to the theory, widely developed by John Ruskin, ${ }^{54}$ that 'the effect of beauty is good. Beautiful painting and sculpture appeal to the better nature of a man'. ${ }^{55}$ Blatchford had always shared Morris's faith in 'the practical values of art':56

In proportion as you can make men's work artistic will it become pleasant and elevating and productive of contentment. In proportion as the work becomes more pleasing, more interesting and more noble will the people grow to love it; and the more the people come to love their work, the more industrious and contented they will be. ${ }^{57}$ 
11 But his faith had significantly increased since he wrote his first utopia. Indeed, in The Sorcery Shop, Blatchford had moved away from the state-controlled socialism advocated by Merrie England to fight against loafers. ${ }^{58}$ The fact that lazy Bernard had not been ostracised and had not been given up on ${ }^{59}$ testifies that Blatchford put his trust in another effective weapon for transforming the human soul - the influence of Nature. Basing himself on the principle that 'man is a creature of circumstances. You cannot separate him from his surroundings or he ceases to exist', ${ }^{60}$ he adhered more than ever to the view that the key to man's contentment was a life in contact with Nature which would almost spontaneously make him good again.

\section{The therapeutic virtues of Nature}

Blatchford, like Morris, belonged to the group of socialists who, actuated by the logic that the natural world makes better men, conceived of their role as consisting in creating a new environment which would breed new desires, and in educating individuals to change their environment: 'The farther we get from nature - the more artificial our lives become - the worse is our health'. ${ }^{61}$ The socialist faith in the mechanics of environmental determinism had its roots in the Enlightenment and found its main expression in Robert Owen's thought and Herbert Spencer ${ }^{62}$. But Blatchford's socialist world appears as the result of a blend of mixed influences also perceptible in Morris. If we can spot a touch of Rousseau in the dietary habits of the Utopians of The Sorcery Shop, ${ }^{63}$ it is undeniable that both men were greatly inspired by the essays of naturalists such as W.H. Hudson et R. Jefferies who spent their lives in close contact with nature and contributed to spreading the belief that it led to real happiness and fulfilment as expressed by Jefferies in his autobiography:

Fullness of physical life causes a deeper desire of soul life... I believe it to be a sacred duty incumbent upon everyone... to encourage their physical life... in every manner. A sacred duty each towards himself and each towards the whole of the human race... Those who stunt their physical life are most certainly stunting their souls. ${ }^{64}$

13 W.H. Hudson (A Crystal Age, 1887) and R. Jefferies (After London; or Wild England, 1885), themselves producers of utopian novels, were very influential writers who not only attributed therapeutic virtues to Nature but also religious ones: 'My hope becomes as broad as the horizon afar reiterated by every leaf, sung on every bough, reflected in the gleam of every flower... Earth holds secrets enough to give them the life of the Fabled Mortals'.65 Although Jefferies's autobiography was published after The Sorcery Shop, Blatchford was very familiar with his previous works such as 'Field and Hedgerow' which he quoted extensively in Merrie England. ${ }^{66}$ Jefferies's life set an example of unbookishness which certainly accounts in part for the absence of formal education observed in Nowhere and The Sorcery Shop ${ }^{67}$. As Jefferies explained, book learning 'was a waste of golden time while the rich sunlight streamed on hill and plain', ${ }^{68}$ an opinion shared by W.H. Hudson who, in his utopia, A Crystal Age, happily proceeded to 'a kind of Savonarola bonfire in which most of the things once valued have been consumed to ashes - politics, religions, systems of philosophy, 'isms and 'ologies of all description; schools'. ${ }^{69}$

The paucity of serious intellectual pursuit in Blatchford's novel certainly finds here an explanation. Significantly like old Hammond in Nowhere, Tomtit Lemon is the only Utopian interested in 'the beginning of life and the descent of man'; ${ }^{70}$ the others seem have 
taken heed of Hudson's advice that scholarship never helped find 'the secret of happiness and all our toil and effort is misdirected ${ }^{71}$. Hudson and Jefferies believed men could cleanse their bodies and their spirits by living again in harmony with Nature and thus recover their original state of perfection which had been stifled and warped by their feverish conquest of the environment. Significantly in The Sorcery Shop the landscape has recovered its natural beauty and the Utopians take constant rapturous delight 'in the skies and fields and flowers and birds' ${ }^{72}$ As in News from Nowhere, they never fail to assemble for the May Festival ritual when 'everybody goes out to enjoy the beauties and joys of the Spring. ${ }^{73}$ Because, as explained by the wizard, this is essential to man's happiness:

Land is necessary to the nation. Without land the people cannot produce nor enjoy the necessaries of life. Without land they cannot have food, clothing, houses nor fuel. They cannot have woods, fields, gardens nor streams. They cannot have air nor exercise nor health. ${ }^{74}$

Unsurprisingly only 'perfect' individuals - of shape and of mind - people his utopia: ${ }^{75}$ 'We have never seen a people so physically handsome, so vigorous. We have never seen such manly men, such womanly women. We have never seen a people so intelligent, so fearless, so free' , wonder the travellers ${ }^{76}$ who pursue: 'High intelligence, sweet good will look frankly from their wonderful eyes'. ${ }^{77}$ When $\mathrm{M}$. Jorkle remarks that such people must be exceptional the wizard replies on the contrary that 'it is true of all women and men under natural conditions' .$^{78}$ But perhaps one of the most active components of Blatchford's socialism was science which, he claimed, 'has enabled us to begin to understand human nature and has made it possible to build up a systematic code of true morality'. ${ }^{79}$

\section{The influence of Lamarckism}

The doctrine that man can be shaped by his environment and his heredity mainly spread in England under the influence of Jean Baptiste de Lamarck who contended that acquired characteristics can be passed on from one generation to another ${ }^{80}$ - an idea fully developed by Samuel Butler in Erewhon in $1872^{81}$ - which convinced a lot of nineteenth-century utopists of the possibility of transforming man until perfection. The preference of Blatchford for Lamarck's rather than Darwin's theories is easily accountable when one discovers that he interpreted the 'struggle for life' as a mere biological extension of laissez-faire which was totally contrary to his communistic ideal: 82

The Survival of the Fittest is a question of conditions... It is another name for Anarchy. Our society is bound by law. The unfettered 'right of individual enterprise' is anarchy. The man who accepts the Laissez-Faire doctrine would allow his garden to run wild so that the roses might fight it out with the weeds and the fittest might survive. ${ }^{83}$

Characteristically, in News from Nowhere, Old Hammond indicates that 'how to take the sting out of heredity for long has been one of the most constant cares of the thoughtful men amongst $u s^{84}$ and claims that "people have got defter in doing the work generation after generation'85 so that 'a tradition of habit has been growing on us and that habit has become a habit of acting on the whole for the best' ${ }^{86}$ In The Sorcery Shop Blatchford obviously banks on the same creed propagated a few years before by Merrie England:

Men are made what they are by two forces, heredity and environment. Your intellect and character are at birth what your forefathers made them. And the 
intellects and characters of your forefathers were what their forefathers and their

own surroundings made them. ${ }^{87}$

It is not surprising therefore that he should believe that the change of ideal and of environment which took place in his socialist world is the guarantee of the endless bliss of man: 'The labourer of this England has in fact everything that is necessary to a happy, healthy and honourable life. ${ }^{88}$ In that sense Blatchford's optimism as regards man's rationality and capacity to change is similar to Morris's if not greater. Although he may have despaired of the crowds - 'I have come to the belief that the great mass of the workers are too apathetic and selfish to be moved and that it is to the younger and the better educated that the champions of Socialism may most profitably appeal' - he did not despair of educating their future leaders and maintained that 'the chief duty of a Socialist pressman is and must be of an educational kind'. ${ }^{99}$ The change that took place in socialist England was indeed of that kind: 'If you could convince them [people] that there are better things than luxury and power and applause and ease and that these more desirable ends could be attained without money they would cease to care for money'. ${ }^{90}$ Trusting that it would not have to come about by revolution as in News From Nowhere but simply thanks 'to the changed ideal of the people to a rearrangement of society upon more practical and more human lines ${ }^{91}$ is irrefragable evidence of his sanguinity.

\section{Conclusion}

In 1907 Blatchford was still a hopeful man. His socialism rested on a belief in the natural goodness of man, the common sense of ordinary people and the transformational power of the environment. But in the years that followed, whether it was age or the Boer War or both, he was indeed to turn about face on a number of issues and gradually move to the right, becoming a passionate advocate of the British Empire. In 1924 the man who had never been interested in plans for tidying up and controlling industrialism but, like Morris, in sweeping away its ugliness, voted for the Conservative Party and, in 1931, The Clarion ceased publication. Perhaps what led him there was the intimate feeling - which occasionally surfaces in his work - that the English masses would never listen because ' $a$ horse race or a Jingo song interests them more' ${ }^{92}$...

\section{NOTES}

1. The same year Morris, with a small number of friends, seceded from the Socialist League and formed the Hammersmith Socialist Society. In fact Morris reorganised a local branch of the League established a few years before at Hammersmith. They met every Sunday evening to discuss 'Art and Life'.

2. Quoted by Lawrence THOMPSON, Robert Blatchford: Portrait of an Englishman, London: Victor Gollancz, 1951, p. 194. 
3. E. Belfort Bax for instance thought that it was futile and looked down on socialist utopias. See Chris WATERS, British Socialists and the Politics of Popular Culture, Manchester: Manchester University Press, 1990, p. 61.

4. A penny edition was also printed and sold 700,000 copies within a year.

5. 'I cannot help thinking that it does not matter what goes in the Clarion this week, because William Morris is dead... He was our best man, and he is dead... Morris was not only a genius, he was a man. Strike at him where you would, he rang true'. Quoted by E.P. THOMPSON, William Morris: Romantic to Revolutionary, London: Lawrence \& Wishart, 1955 (London: Merlin Press, 1997, p. 638).

6. 'We do not wish to quarrel with the Labour Party... but our party is not their party'. Quoted by L. THOMPSON, Robert Blatchford: Portrait of an Englishman, p. 194.

7. Ibid, p. 194.

8. Chris WATERS, British Socialists and the Politics of Popular Culture, p. 56.

9. Author's Note to The Sorcery Shop: An Impossible Romance, London: The Clarion Press, 1907.

10. William MORRIS, News From Nowhere, with an Introduction by Andrew L. Morton, London: Lawrence \& Wishart, 1973, p. 401.

11. Samuel Jorkle is the Liberal MP and General Storm the Conservative one.

12. The Sorcery Shop, p. 2.

13. The Sorcery Shop, p. 14.

14. Ibid., p. 14.

15. Although Blatchford seems to prefer the Italian Renaissance with its 'domes and towers of marble palaces, and the graceful shaft of a tall campanile with a gleaming golden crown' to the Middle Ages. The Sorcery Shop, p.16.

16. The Sorcery Shop, p. 48. There is no need for divorce laws: 'A woman leaves when her husband ceases to love her', p.46.

17. William MORRIS, 'The worker's share of art', Commonweal, vol. 1, n³ (April 1885), p. 19 (Reproduit dans William MORRIS, Political Writings : Contributions to Justice and Commonweal, 1883-1890, Edited and Introduced by Nicholas Salmon, Bristol: Thoemmes Press, 1994, p. 87.)

18. The Sorcery Shop, p. 123.

19. Ibid., p. 125.

20. Ibid., p. 121.

21. Ibid., p. 100.

22. 'Socialism does not mean the sharing out of property ... It means the collective ownership of property', quoted by L. THOMPSON, Robert Blatchford, Portrait of an Englishman, p. 175.

23. The Sorcery Shop, p. 45. 'The foundation and pattern of the State is the family', ibid.

24. 'They pick up botany, astronomy, geography, gardening'. The Sorcery Shop, p. 60.

25. Ibid., p. 60.

26. The Sorcery Shop , p.139.

27. Ibid., pp. 131 and 135.

28. Ibid., p. 137.

29. Ibid., p. 71.

30. Ibid., p. 188.

31. Ibid., pp. 153-165.

32. Ibid., p. 193. People are teetotallers, p. 25.

33. Ibid., pp. 109 and 129.

34. Ibid., p. 194.

35. Ibid., p. 111.

36. Ibid., p. 109.

37. Ibid., pp. 100 and 125.

38. The Sorcery Shop, p. 110.

39. Ibid., p. 111. 
40. Ibid., p. 47 or 85.

41. 'The wicked are more agreeable and more interesting. They generally know more than the righteous and they are always a lot more charitable. I don't see how a man who never did wrong and never had any trouble, who was never ashamed of himself, and never weary of his life with sorrow can be considered a complete specimen. He is not a finished man. He may be true metal but he has never been tempered' Quoted by L. THOMPSON, Robert Blatchford: Portrait of an Englishman, p. 68.

42. Ibid, p.59.

43. 'I have known many men and have studied them. I know none perfect; few near to perfection; not a great many who are more gold than dross; most of all those many faults are atoned for by some few excellencies. Take conditions into account. Study the question earnestly and with a desire to see your fellowmen at their best... If you give human nature some mercy and extenuation you will find that there are merits where you never suspected them to exist... Peel off the husks of ignorance, habit, eccentricity and the selfishness and callousness which are caused by the circumstances of life... you will agree with me that men are not such bad fellows after all', ibid , p. 46.

44. The Sorcery Shop, p. 115.

45. Ibid., p. 101.

46. Quoted by L. THOMPSON, Robert Blatchford: Portrait of an Englishman, p. 162.

47. Ibid, p. 68.

48. The Sorcery Shop, p. 101.

49. Ibid., p. 98.

50. Ibid., p. 61.

51. Ibid., p. 62.

52. Ibid., p. 99.

53. 'I know two brothers who did not speak for months because one of them got a job as a mason there and the other was too late'. The Sorcery Shop, p. 86.

54. 'Most of those who are worth anything have been touched by Ruskin's writings and converted into socialists of some kind' (William MORRIS, The Present Outlook in Politics, quoted by Paul MEIER, La pensée utopique de William Morris, Paris: Éditions sociales, 1972, p. 148). Unsurprisingly Blatchford read Ruskin, who is quoted extensively in Merrie England.

55. The Sorcery Shop, p. 90.

56. Robert BLATCHFORD, Merrie England, London: Clarion Press, 1894, p. 156.

57. Merrie England, p. 156.

58. 'The State would not compel any man to work...If a man did not choose to work he would not be coerced...But if he declined to work he would certainly have to starve or to leave the State'. Merrie England, p. 145.

59. 'We can do nothing but wait', declares the wizard. The Utopians hope to transform him by loving care, The Sorcery Shop, p. 71.

60. Merrie England, p. 114.

61. Ibid., p. 16.

62. See for instance W.H.G. ARMYTAGE, Heavens Below: Utopian Experiments in England, London: Routedge \& Kegan Paul, 1961.

63. 'There is not a drop of wine, spirits or beer in the country'. Lunch consists of 'soup, a curry with rice, pumpkin pie, potato straws, stuffed olives'. Meat is unknown, they do not smoke either. The Sorcery Shop, pp. 23-24. The ideal diet is fully developed in Merrie England. See J.J. ROUSSEAU, Discours sur l'origine de l'inégalité (1754): 'Les aliments trop recherchés des riches, qui les nourrissent de sucs échauffants et les accablent d'indigestion, la mauvaise nourriture des pauvres... voilà les funestes garants... de nos maux'. (Paris : 10/18. Union Générale d'Éditions, 1963, p. 261).

64. Richard JEFFERIES, The Story of my Heart: My Autobiography, London: Longmans Green \& Co, 1913, p. 125.

65. Richard JEFFERIES, The Life of the Fields, London: Chatto \& Windus, 1904, p. 4. 
66. Merrie England, p. 36.

67. One also thinks of course of the undeniable influence of Rousseau's Émile.

68. Richard JEFFERIES, The Story of my Heart, p. 24.

69. W.H. HUDSON, A Crystal Age, New York: AMS Press, 1887, p.228.

70. The Sorcery Shop, p. 81.

71. W.H. HUDSON, A Crystal Age, p. 229.

72. The Sorcery Shop, p.102.

73. Ibid., p. 102.

74. Ibid., p. 174.

75. Ibid., p. 94.

76. The Sorcery Shop, p. 29.

77. Ibid., p. 33.

78. Ibid., p.129.

79. L. THOMPSON, Robert Blatchford: Portrait of an Englishman, p. 176.

80. Cf. J.B. LAMARCK, Pages choisies, Paris: Éditions sociales, 1957. On Lamarck's influence see for instance R.W. BURKHARDT Jr., The Spirit of the System, Harvard University Press, 1977.

81. 'The course of any germ's development was dictated by the habits of the germs from which it was descended, and whose identity it had once formed part. If a germ found itself placed as the germs on the line of its ancestry were placed, it would do as its ancestors had done, and grow up into the same kind of organism as theirs'. S. BUTLER, Erewhon, Harmondsworth: Penguin Books, 1976, pp. 236-237.

82. 'My ideal is that each individual should seek his advantage in cooperation with his fellows and that the people should make the best of their own country before attempting to trade with other peoples'. Merrie England, p.12.

83. Ibid., p. 134.

84. News From Nowhere, p. 243.

85. Ibid, p. 280.

86. News from Nowhere, p. 262.

87. Merrie England, p. 75.

88. The Sorcery Shop, p. 118.

89. Quoted by L. THOMPSON, Robert Blatchford: Portrait of an Englishman, p.162.

90. The Sorcery Shop, p. 113.

91. Ibid., p. 189.

92. As he confided one day to his biographer Lawrence Thompson. See L. THOMPSON, Robert Blatchford: Portrait of an Englishman, p. 151.

\section{ABSTRACTS}

William Morris and Robert Blatchford were amongst the reformers at the end of the nineteenth century who fought relentlessly for the advent of socialism in England. Convinced of men's perfectibility once their country was rid of the environmental misery that capitalism had brought in its wake, and had recovered its architectural and natural beauty, they believed in Utopia as an effective means of propaganda for the workers. This article underlines the heavy debt of Blatchford's The Sorcery Shop to Morris's News From Nowhere and the common roots of their socialist faith. 
William Morris et Robert Blatchford font partie des réformateurs qui à la fin du dix-neuvième siècle luttèrent sans relâche pour l'avènement du socialisme en Angleterre. Convaincus de la perfectibilité de l'homme une fois que le pays, débarrassé des dégâts environnementaux engendrés par le capitalisme, aurait retrouvé sa beauté naturelle et architecturale, ils virent dans l'utopie un moyen de propagande efficace sur les ouvriers. Cet article souligne la dette de The Sorcery Shop de Robert Blatchford envers News From Nowhere de William Morris et les racines communes de leur foi dans le socialisme.

\section{AUTHOR}

\section{MARTINE FARAUT}

Université de Nice-Sophia Antipolis 